2. Макарова И.Н. Индивидуально-психологические особенности личности как фактор межличностных отношений в волонтерских объединениях // Олимпийский Сочи: Социум. Культура. Личность: Материалы 5-й Всерос. науч.-практ. конф., г. Сочи, 4-6 октября 2012 г. / Отв. ред. И.Н. Макарова, Е.В. Поступинская. - Сочи: РИЦ СГУ, 2012. С.12-28.

\title{
ОСОБЕННОСТИ ПСИХОЛОГИЧЕСКОЙ АДАПТАЦИИ МОЛОДЕЖИ ВО ВРЕМЯ ПРОФИЛЬНОЙ СМЕНЫ (НА ПРИМЕРЕ СМОЛЕНСКИХ ОБЛАСТНЫХ СБОРОВ ТВОРЧЕСКОЙ МОЛОДЕЖИ) \\ Сидоренков, А.С., Морозикова И.В.
}

Летний отдых важен для полноценного развития детей, и его содержанию и качеству следует уделять особое внимание. В это время ребенок имеет много свободного времени и возможность отдохнуть от напряженного учебного года и набраться сил для нового. Государство обязуется принимать меры по обеспечению максимальной доступности услуг организации отдыха детей и их оздоровления, что согласуется с Федеральным законом от 24.07.1998 N 124-Ф3 (ред. от 28.12.2016) «Об основных гарантиях прав ребенка в Российской Федерации» [8]. Одним из популярных видов детского отдыха является летний оздоровительный лагерь. За время, проведенное в нем, кроме физического оздоровления, дети набираются опыта общения с коллективом, раскрывают свои творческие способности и т.п. Сейчас в России организуется большое количество детских лагерей разного уровня (языковые и профильные лагеря, направленные на развитие лидерских качеств, творческих способностей и т.д.). И одной из главных проблем такого отдыха является то, что дети, попав в новые социальные условия (новый детский коллектив, коллектив вожатых) могут испытывать проблемы с адаптацией к этим новым условиям, особенно в первые дни пребывания. Понимание особенностей психологической адаптации молодежи во время организационного периода профильной смены требует изучения и определяет актуальность исследования.

В отечественной психологии изучением проблемы психологической адаптации детей занимались такие ученые, как Д.Н. Дубровин, А.В.Петровский, А.А.Реан, А.В.Морозов и др.

Так, Д.Н.Дубровин под психологической адаптацией, понимает единство и взаимодействие социальной и личностной адаптации к современной жизни [2]. А.А. Реан рассматривает социально-психологическую адаптацию как активное самоизменение личности в соответствии с требованиями ситуации [5]. В.М.Шепель считает, что адаптация - это процесс приспособления личности к социально-психологическим условиям среды [10].

Таким образом, под адаптацией можно рассматривать, процесс приспособления как внутренних функций организма к условиям внешней среды, так и личности индивида к социально-психологическим условиям среды. С этой точки зрения, психологическая адаптация - приспособление человека к 
существующим в обществе требованиям и критериям оценки за счет присвоения норм и ценностей данного общества [1].

Необходимо отметить, что активно изучалась структура психологической адаптации (Н.В. Литвиненко, Т.Д. Молодцова, И.Р. Перережко, И.А. Фурманов, Т.Н. Вершинина и др.). Например, А.В. Морозов выделяет такие структурные компоненты адаптации, как физиологический, психологический, социальный. Д.Н. Дубровин, напротив, выделяет всего один компонент - психологический и подразделяет его на социальный и личностный [2].

Как считает Н.Б. Челдышева, социально-психологическая адаптация - это интегративный показатель состояния человека, отражающий его возможности выполнять определенные биосоциальные функции: 1) адекватное восприятие окружающей действительности и собственного организма; 2) адекватная система отношений и общения с окружающими, способность к труду, обучению, к организации досуга и отдыха; 3) изменчивость (адаптивность) поведения в соответствии с ролевыми ожиданиями других. Так же она выделяет стадии процесса социально-психологической адаптации: а) ознакомление; б) ролевая ориентация; в) самоутверждение [9].

У одних участников адаптация происходит быстро и незаметно, у других может затянуться на всю смену или не произойти вовсе. В плане психологической адаптации зачастую перевод ребенка из одного профиля в другой не всегда приводит к положительному результату, а порой даже к отъезду ребенка из лагеря.

С целью понимания особенностей психологической адаптации молодежи во время организационного периода профильной смены было проведено исследование на примере профильной смены Смоленских областных сборов творческой молодежи, в котором принимали участие участники смены (юноши и девушки) в возрасте от 14 до 18 лет в количестве 240 человек.

Для выявления особенностей психологической адаптации использовались следующие методы: теоретический анализ литературы, наблюдение, математическая обработка данных. Из психодиагностических методов была использована методика оценки психических состояний В.А. Доскина «Тест дифференцированной самооценки функционального состояния», модифицированная нами для условий сборов [3].

По результатам методики были получены данные шкал настроения и самочувствия за весь период профильной смены «Сокол-2016» [Таблица 1, 2].

Таблица 1 «Настроение» и «Самочувствие»

\begin{tabular}{|l|c|c|c|c|c|c|c|}
\hline Настроение & $\mathbf{1}$ день & $\mathbf{2}$ день & $\mathbf{3}$ день & $\mathbf{4}$ день & $\mathbf{6}$ день & $\mathbf{7}$ день & $\mathbf{9}$ день \\
\hline Восторженное & 60 & 66.2 & 42.9 & 82.4 & 76.5 & 80.3 & 55.2 \\
\hline Хорошее & 34 & 31.9 & 47.9 & 16.1 & 20.25 & 16.6 & 25.7 \\
\hline Тревожное & 5 & 1.4 & 7.6 & 1.5 & 3 & 2.2 & 5.2 \\
\hline Хочу домой & 1 & 0.5 & 1.5 & 0 & 0.5 & 1.7 & 1.2 \\
\hline Самочувствие & $\mathbf{1}$ день & $\mathbf{2}$ день & $\mathbf{3}$ день & $\mathbf{4}$ день & $\mathbf{6}$ день & $\mathbf{7}$ день & $\mathbf{9}$ день \\
\hline Прекрасное & 50.7 & 64 & 43.6 & 75.1 & 60.8 & 60.9 & 50 \\
\hline Хорошее & 33.2 & 25.4 & 30.9 & 21.5 & 25.6 & 31.7 & 27.7 \\
\hline Устал, но силы есть & 15 & 8.2 & 19.6 & 2.9 & 10.9 & 6 & 6.4 \\
\hline Почти умер & 1 & 2.4 & 5.9 & 0.5 & 2.7 & 1.4 & 3.4 \\
\hline
\end{tabular}


В 1 день 60\% детей отметили «восторженное» настроение, 34\% «хорошее», 5\% - «тревожное» и всего 1\% детей «хотел домой». Результаты по школе говорят о том, что в целом участники находились в хорошем настроении.

Это обусловлено тем, что в 1 день участники не испытывали особой нагрузки мероприятиями и у них было много времени на общение друг с другом. Также для формирования отношений и сближения между членами фил в этот день была проведена спортивная игра на местности «Быстрее. Выше. Сильнее». Она была направлена на то, чтобы участники смогли узнать друг друга в ситуациях прохождения испытаний, и в конце концов сформировать общую цель, направленную на победу (в данном случае). Таким образом, участники преследуют цель - победить в игре, а сама спортивная игра позволяет положить начало для формирования и сближения детского коллектива.

На второй день ситуация со школой «Настроение» практически аналогична первому (в целом участники находились в хорошем настроении), а процент детей, желающих уехать снизился и составляет всего $0,5 \%$.

Переломный период наступает на 3 день. В этот день процент «хочу домой» увеличился и составляет 1,5\% детей [таблица 1]. А такие показатели настроения, как «восторженное» и «хорошее», упали ниже 50\%. Необходимо отметить, что к этому времени в филе и в профиле выделяются лидеры, и возникают межличностные конфликты между участниками на почве лидерства. Это и провоцирует у некоторых детей возникновение настроения «уехать домой». На особую напряженность третьего дня указывает также шкала самочувствия - 5,9\% участников «почти умерли». Здесь сказывается не только физическая усталость (не все дети привыкли к спортивным мероприятиям), но и психологическая (не все участники умеют справляться со своими эмоциональными переживаниями, готовы к активной творческой деятельности).

По результатам четвертого дня [таблица 1] настроение участников улучшается, а процент желающих уехать, равен нулю.

Таким образом, третий день становится критическим: если участники в этот день они не покидают лагерь, то, как правило, без особых причин (болезнь и т.д.) они не уезжают. Можно говорить о том, что если ребенку удается преодолеть этот период, то его психологическая адаптация к условиям новой среды прошла успешно: участник сборов смог выстроить у себя систему отношений и общения с окружающими, позволяющую ему комфортно трудиться, обучаться, организовывать досуг и отдых.

После анализа шкал за весь период профильной смены, мы выделили еще 3 дня в которые отражают желание детей уехать - это 6,7 и 9 дни. $0.5 \%, 1.7 \%$ и $1.2 \%$ «хочу домой» соответственно [Таблица 1 Самочувствие]. Такие показатели связаны с небольшой усталость от насыщенной программы сборов, так как показатель прекрасного самочувствия держится на уровне $60 \%$ в 6 и 7 дни, а в 9 день он снижается до 50\% [Таблица 1 Настроение]. 
Таким образом, психологическая адаптация молодежи во время организационного периода профильной смены имеет свои особенности. Первые дни профильной смены являются самыми трудными для детей. При этом третий день становится критическим: в это время у участников смены снижается настроение, ухудшается самочувствие. Во многом такая ситуация связана с изменением привычного образа жизни (изменение распорядка дня, активная спортивная и творческая деятельность), сложностями в ролевой ориентации ребенка (выделение лидеров, налаживание отношений с членами филы). Понимание и учет особенностей психологической адаптации детей во время организационного периода смены позволит оптимизировать работу в детских оздоровительных лагерях.

\section{Литература}

1. Большая

психологическая

энциклопедия.

URL: http://onlineslovari.com/bolshaya_psihologicheskaya_entsiklopediya/page/psihologic heskaya_adaptatsiya.5128/ (дата обращения: 29.03.2017)

2. Дубровин Д.Н. Психологическая адаптация как фактор личностного самоопределения: автореф. дис. ... канд. психол. наук: Москва, 2005. - 135 с.

3. Доскин В.А., Лаврентьева Н.А., Шарай В.Б. и Мирошников М.П. Тест дифференцированной самооценки функционального состояния // Вопросы психологии. 1973. № 6

4. Морозов А.В. Деловая психология. СПб.: Издательство Союз, 2000. $355 \mathrm{c}$.

5. Реан А.А. Психология адаптации личности. СПб.: Прайм-ЕВРОЗНАК, 2008. - $479 \mathrm{c}$.

6. Смоленские областные сборы творческой молодежи «Сокол - 2016» Учебно-методическое пособие и рабочая тетрадь для участников и организаторов профильного лагеря/ под ред. Н.П. Сенченкова. - Смоленск, 2016. - 97 c.

7. Социология в России / Под ред. В.А. Ядова. -2-е изд., перераб. и дополн. - М.: Издательство Института социологии РАН, 1998. - 696 с.

8. Ф3 от 24.07.1998 N 124-Ф3 (ред. от 28.12.2016) "Об основных гарантиях прав ребенка в Российской Федерации».

9. Челдышева Н.Б. Шпаргалка по социальной психологии. URL: https://psy.wikireading.ru/22006 (дата обращения: 29.03.2017).

10. Шепель В.М. Социально-психологические проблемы воспитания. М.: Московский рабочий, 1997. - 450c.

\section{ДИСТАНЦИОННОЕ ОБУЧЕНИЕ И ОСОБЕННОСТИ ПРОФЕССИОНАЛЬНОГО САМООПРЕДЕЛЕНИЯ СТАРШЕКЛАССНИКОВ}

Прокофьева В.A.

В связи с переходом к рынку наблюдается появление новых профессий, повышение требований к подготовке кадров, увеличение спроса на 